Repart of Inweatigatione by Howard M. Powlor

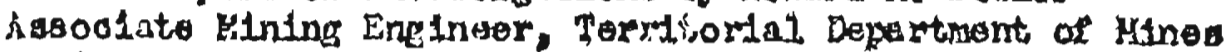
In tho Potorsburg-Kotohtkan Mintne Proolnata, Alaka Mar 30 - August 1, 1948<smiles>CCCCCC</smiles>

May 30 - Jungau to Petorabuspe.

I5. S. Hungersord of Patergburg who has been engaged in lapldary work hes laft Potergbure for Portland. It is bollevod to be perment.

Sar 32 -

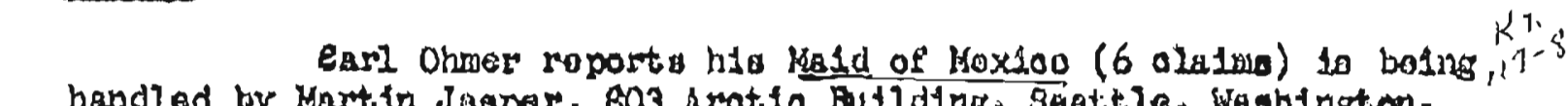
handled by Wart in Jaeper, 803 srotio Butldths, 3eattie, Weshington.

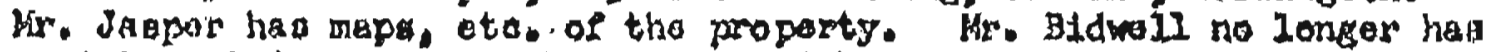
an interest In the property. Solo tytin rests with kif. Ohener. Thero 1s no ativity at prosont at tho property.

, the clatar of Jaok Sahoonovar on Ty lox Oronk, Duncan Canal, Kuproanos Iriand. Wr. Backett in In ohargo of C. A. A. Installations at Indian Polnt and Poteraburg.

oould not ontented.

Hr. Hlokn, U. S. Oormatalonor, wa aboont srom town and Juno 1 -

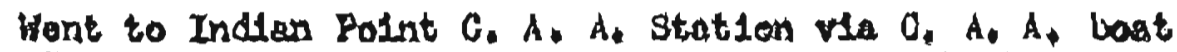
M. 3. Civate H. Taken to Jaok Sohoonover proporty on Teylor Creak by $N .3$, C Ivale 1 and outboard.

Sing $2-3-$

Examined gchoonovex proparty. The rivor wa high due

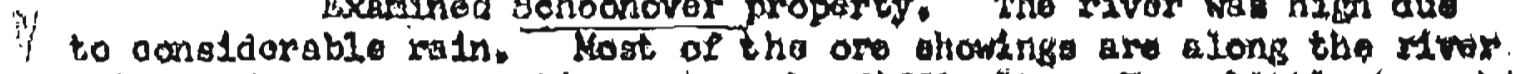
whioh mede proper aempling oxtronely diffloult. Vory littlo tronohing 
has been done and 3t. Schoonover had no ahovel at tho property. Ten samples wore cut of which four wero dieok anples.

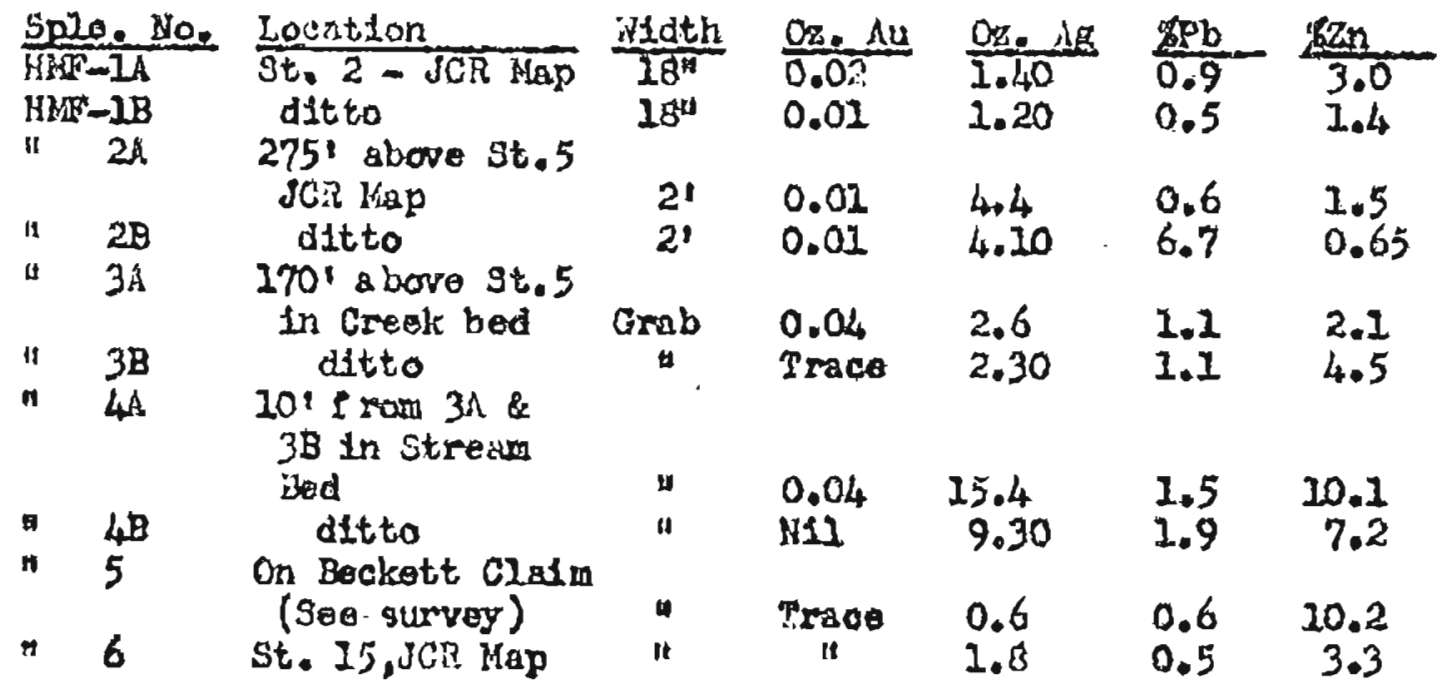

Several mineralized atmingers 12 inches to 3 Peot wide and with tive nortin strike joined the acid dike on the north ot de along the river.

Futher minerallgation $1 \mathrm{~s}$ evident on the h1ll several hundred jarde to the nortlb. Hr. Schoonover plang to further prospect tho aree and in op opinion it iv fully justified.

Iuno 3 - Vrening - Trylor Crogk to Indar Point.

June 4 - Indian Point to Potersburg.

(. Contacted Ifr. Hicks, U, S. Commiosionar, Isesc and Honry Kataso have lacated 10 lodo clalms (called Katase Lede Graup) approxinately 3 rifles wat of Portage Bay. Kuprennol Inland. I was unablo to dotemine the nature of the clains or the plans of tho Katago's as they waro flahing at the tire.

June 5 - Paterskurg to Ketohilean.

June ?.

To Koth lay to look over ainc-copper property. Ihis property hrg alroady been oxomined and mampled by the O. S. Bureas of Hines. Sy Inopoction was made to familiarize myoelf with a mas ofneral occurrence of the area. Aner Erlokson and associates 
raportadis have an option on the proparts eroun Hr. Eustroan of senttle, prosent owner of the property. The Palrbanks Nining Carporation has ropartodiy ataked orer those clatm under the ascuption that the orlginal clatmo were not corretly atakad. Lowover, the Noth Bay olaims are patented alairs so the Falrbenks Mining Comporation staking cannot be valid.

Juno B- Kotohtkan Atr Serv100 voathered in.

Juno 2 - To Whaney kine George Inlet. $2 x-120$

At the the of the raterg visit, two wen were actively engaged at the operation. One man hadled mill dut1es and the other took care of the wine. A woran and two mall children - fornty of on of the wan - aloo presute at the groperty.

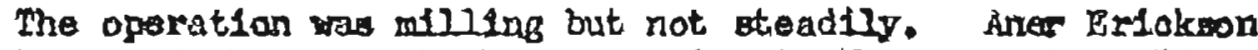
is otill in oharge of the property but, acoording to the cren, he seldom visita it.

Saf'ety conditions are unsatiafactory in both the ahis and aill. Theze are do gtuliz in atopor araas. stopes are open from drift 0 to gurface and no protection has been provided to prowont 10080 rock from if Falline on men in drift. There aro no guard ralla around bead of mil and footing there is aften allek and troscherous. This is txte around

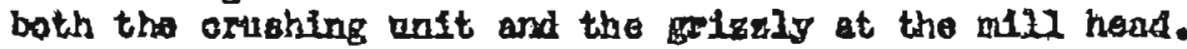

The will has muromous shafts, bolts, and puliay axpost.

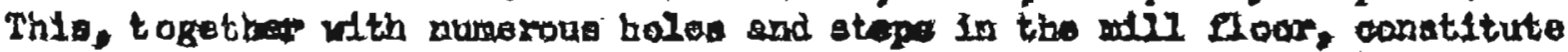

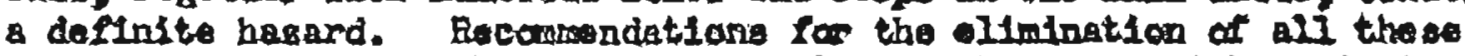
hezards were to the onow at the mine and to Aner Erloken in tom.

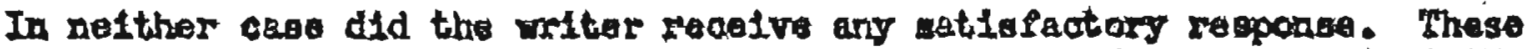
reconmendatlons are easentlally the some as ado by J. C. Hoobm in 1947, lut bave been totally diaragaidod.

Since thig inspection. this property has been taken over by Arthur Theis and ossoctates mo have been ongated in dorelopant at

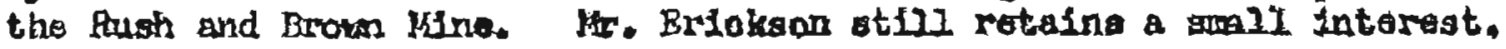

Ingmadiate plang are for the congtruction of a larger osmp

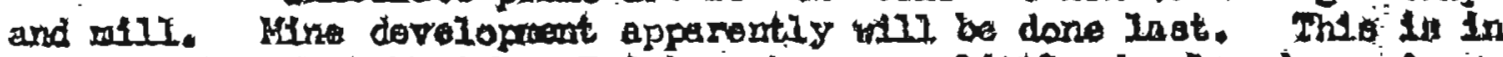
opite of the faot that III. Exlokeon has vary Ilttio davolopsd ore In stejt.

Jung 10 - Return from Hahoner Hine.

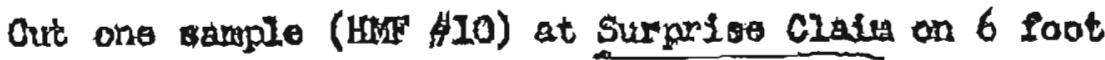


quartz outcrop. Very littlo inerallzation was evident. The rein

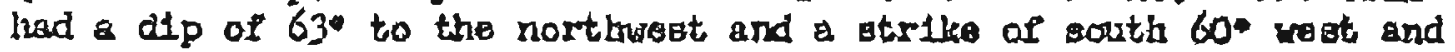
autcrops at tho routh of a short tunnal. There la no present comor.

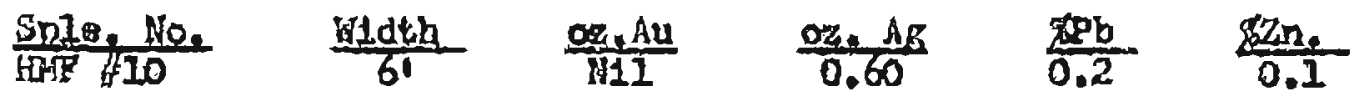

A GFab samplo (IOF (111) was taken on some fron atained slide rook one fourth mite south of the surprise olsim.

$\frac{\text { Sple. Ho. }}{\text { HMF ifII }} \frac{\text { Width }}{\text { Grab }} \quad \frac{\text { gr. Au }}{\text { Trace }} \cdot \frac{\text { Qz. AR }}{\text { HJI }}$

Jung 11 - Lade arrangemants for Pxinoe of Waree Igland examinat ions:

Jure 12 = Loft for Cholmondeloy Sound, Prince of Valer Island, abaard boat Salmon Bay with Iim Plaher, Ceorge Roborly, and Cearge Roberte fanily.

June 13 - Exemined Georgo Roberta clatm called Polymetal Lodo on Solth axw of Cholmondeloy Scand. The Polywatal Lodo is a zincmlead prospect ataked in Maj, 1947 by Hr. Roberta, of Ketohikan.

The ore zone is on inpregration of sedineatis with gulpldes. Insufflolen! tronohing has bas done to dolinit the oreboty. Tho ore outcrope at about 780 raet alevstion and 19 baut 20 feet wida. It dieappears to the south undor a jor alldo area. It lis treoeablo to the north for about 100 foet. A turral wo startod at the 500 level and driven for about 294 fect but did not interwoot the ore. A Bruntan A corapass - Paulin Altineter ourres indicatod that the tunnel would ho adranced far about 203 leet mare in ordar to $X$-ast tho orebody. Hor

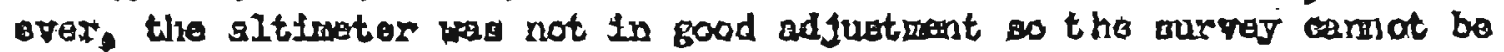
conejdered accurato. Four sarplas more cut an tho outorop.

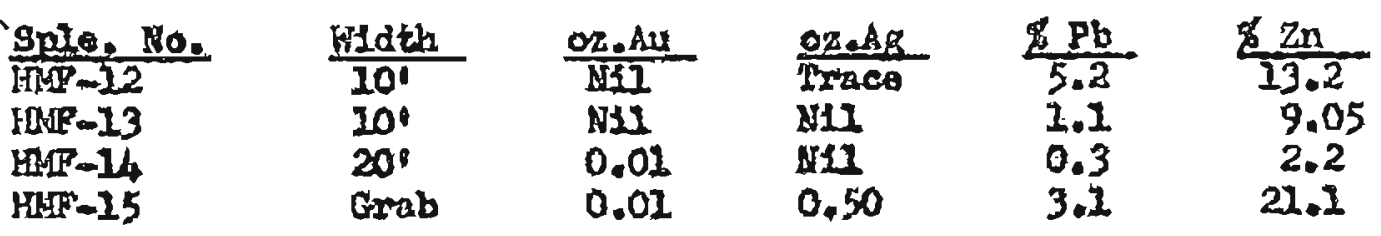

Thase easeys are ancouragtng and if Mr. Roburta doss ans added trenching and development work, a further exramination and reeurvoy will be waranted. A report has been witten on the proports and o oopg sont to Kr. Mobarts.

June 14 - Outboand tor refugde to operate. Howed to Yoonsine Gill alte on wouth arm of Cholmotdeley Sound. 
Jure 15 - Went to keonghine proporty The trakl is comploteIy overgnom for wost of Ita longth. $\Lambda 11$ briogos are either down or completely rottan. pho turnel portal (oluvation 22001) was campletely rililod wh th mow so that entrance into tho turnel wa not pous1810. On top of the ridge beck of the tunnel and at an elevation of 2400', a ghofi has boon ounk on a wall dseinst flowro containing prinolpally galena with quarts, olderite, and caleite. The flosure traverseg a lintestore over pert of its distanoe and tho orebots is locally a pparentiy a raplaceicent body in tho limestara." It was not possiblo to do much investigating a round the shaft as I ra alane and abaft timbor's wore not in vory good ahape. Dropth of ohaft wo undotcrafinod.

Shortiy after the writer's visit to this property David and Bert Swoetsor, sons of a forrer Alakka minine operutar, came to Alagka for the oxcrase purpase of wamining the Moonshine property. They dropped their upplites from the air, last most of them, and an a coneequence did not stay at the property long. However, they reported that tbey had done game woxk in the shalt and bod expored a emall amount of are. They reported that thay dosm cended 72 feot dowa the sheft but did not reach ohaft bottcor.

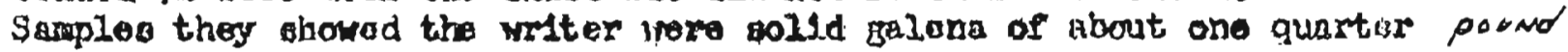

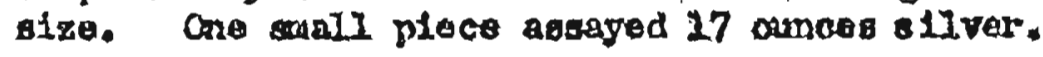

Tho Swetsers otaked the proparty but it 19 doubt tal If thay will roturn to work 1t. Ther gtited they had been suining In the Kohave Dobert in Calfornis and did not think mah of operating conditiona as thay them in Alakka.

June 26 - Outboard motor otill refuaes to run. Rowad to Art gettjo:s logelng camp at mouth of Dore Bay. On Divide Herd, Chnlecondeloy Gaund,

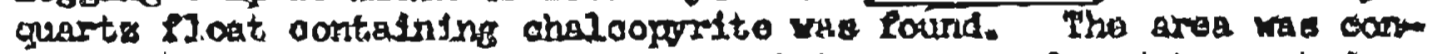
alderably cut wth quarta otringera but now wepe found to contain

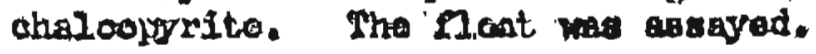

\begin{tabular}{|c|c|c|c|c|}
\hline Spla. Nas & WEath & $O_{2} \cdot A u$ & Ox. Ax & Ex. \\
\hline $\begin{array}{l}H A F-26 \\
5 M-17\end{array}$ & $\begin{array}{l}\text { llant } \\
\text { Ploat }\end{array}$ & $\begin{array}{l}\text { Trace } \\
\text { N11 }\end{array}$ & $\begin{array}{l}0.70 \\
\text { Treos }\end{array}$ & $\begin{array}{l}2.92 \\
2.02\end{array}$ \\
\hline
\end{tabular}

June 17 - Examined Oregon-Idaho property on Dare Isake. Portal of tunnel was oaved but ontry was posalblo. Water had baokod up behind

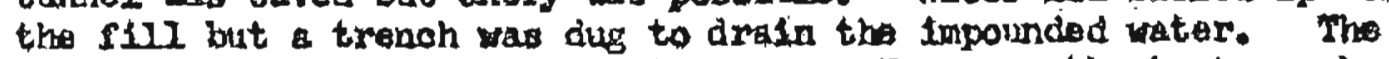
property was ourveyed and osiplors out. Horevor, tho best are had 
apparentiy been stoped out. The shaft ras flooded and acease to lover workings was not possible.

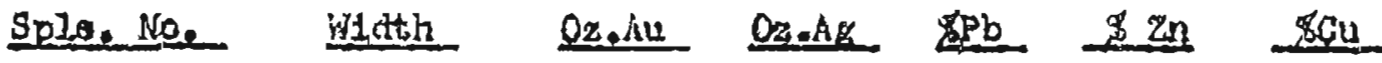

$\begin{array}{lllllll}H M & 71 & 0.01 & 0.40 & 0.02 & 2.6 & 0.04\end{array}$

HNF -19

$M M F=20$

69

0.02

2.6

0.40

0.01

1.2

Trace $2.5 \quad 8.23$

HBIF-2I

Gitab 31 0.14

I.OS

1.5

24.1

$-$

Iune IE-12 - Attemrted to flas plane.

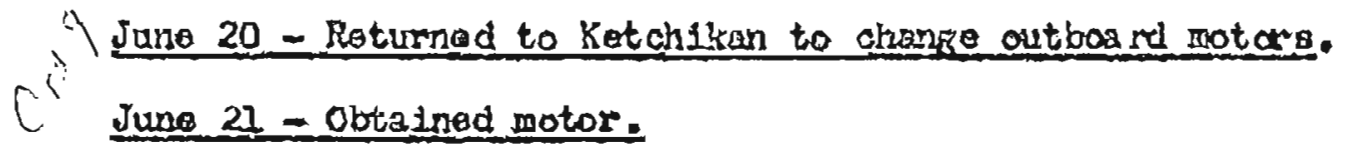

Iuns $22^{\prime 2}$ - Roturnod to Cholmondeley Sound.

June 23 - Left for Dálont $(4,00 \mathrm{~A}$. H.)

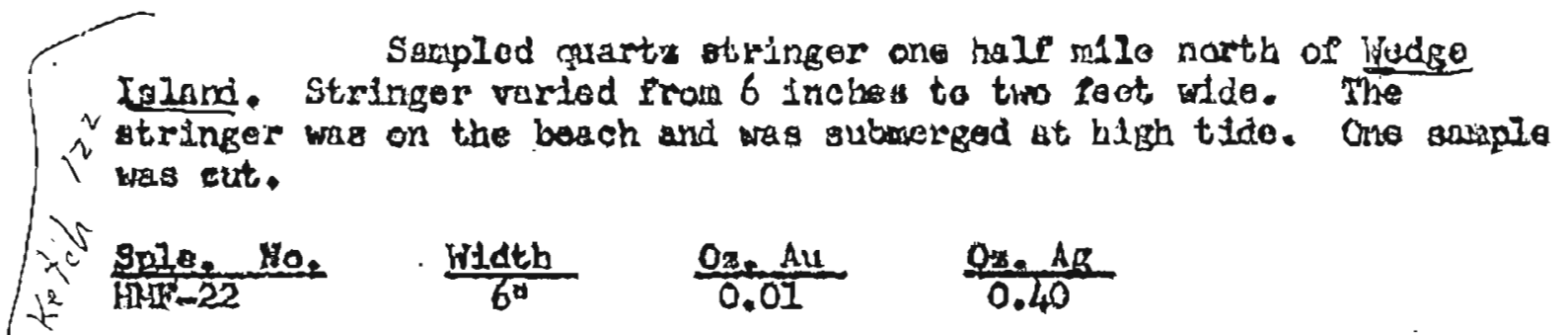

$\checkmark$ atringer was on the boach and was suburerged at bligh tide. One gaple was sut.

tring

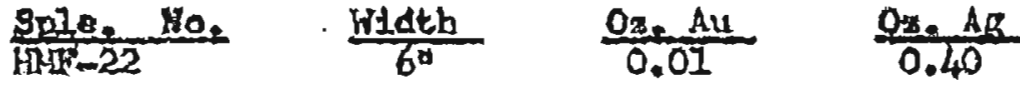

Axplved Dolont Kine. Rolnie Twoet wa in charge. only $k \times-119-31$ weven men wero at the property. Anor Briakson was no longer comnected whith the compeny.

A Tho tram lino srom the berach is rotting badiy and is not

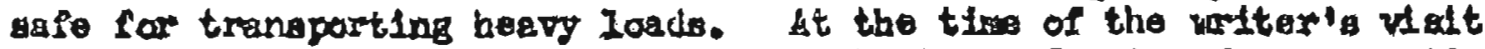
the compeng was not operating lue to a shortage of water for generating power. Ln atterno va beini rado to dewater the rino but the pump

- (N olre wis too irg il do dewater more than the first lovol.

Later, In a talk with Habert Crowe-Swade of Vanourar, B. C., who is backing Dolons. Mr. Crowo-swords atated that he now

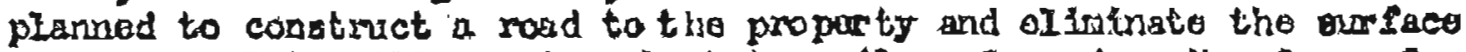
trasway. This will requite ebout two mlles of road. Mr. Crome-Swardo also atated that ho intonded to frutall a dlesel on tho beadi to generato porer for dry perlods of the year when water la low.

June 24- Laft Dolow for H1biack. Weather atorus and waves hiph. Iay to in cove. 


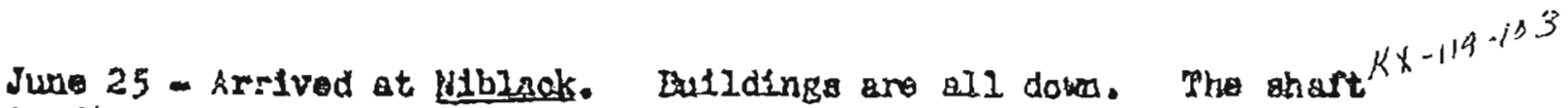
Is Ilooded and Is partially oaved. Small pleces of hematito wre lound on the durp. Ho saplea wore takn. Left llibleok for Kagaan. Heather otory and wares high. Inay to in cove.

June 26. - Iay to in cove most of dey. Weather otorra. Waves guicted dow slightly toward evening so larted up oolst. Rocelved

$\therefore$ tow from flohing bast. Arriged at Grindell Island aboust 1,00 A. M.,

¿ Juno 27.

i.

June 27 - Lanve for Kassan. Looked ovar Rich Hill Kine. This

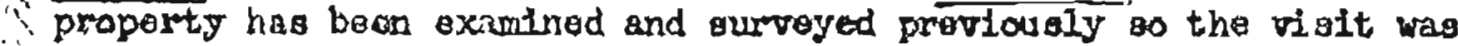
confined to a general Inapeotion. All tunnels ars atill open. A amall amount of copper ore in in aight. Howover, tho aerial trasuray 1a down. Tunkhouses and bulldings ato still otanding. Frod kokay is the ownar. IIr. Mokag states that he hapes to work on the property within the year.

Arrived at Kassan.

Kassan to Coor Bay.

June 20 - Happy Montpleasure was unakle to show the $\cos 18$ oam outm crop until lator.

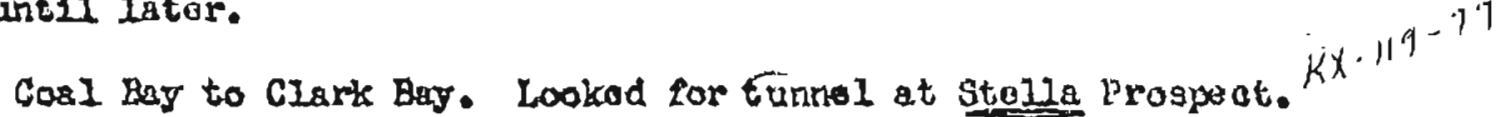
Could not looste the tunnel but ton inch outorop to the veln vas found. The outorop loonted a bout $\$ / 4$ mise fran the beach in the bed of a stream and at an elovetion of 440 feet. The viin lo a quarte porphory in elate. At 1to outorop, it hes a strilice of $\mathrm{N} .45 \circ \mathrm{H}$. and a dip of BO NE. Locally, it l1es in the plen of tho country nook. grall amounts of galona, sphalerito, and pyrito ould be oeen acottered throughout the quartz. One samplo was cut.

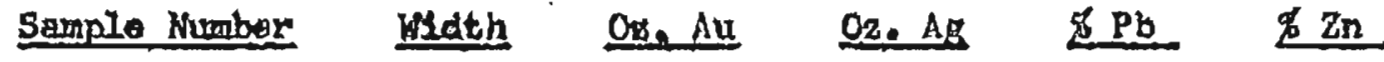

$\begin{array}{lllllll}\text { HWF-23 } & \text { IO } & & 0.02 & 0.60 & 1.2 & 2.6\end{array}$

\section{Clark Bny to Holl18.}

Jun 29 - Inspected Wendell Daweon_ntne on Harris Croek. Kr. Dawson $k x-119-8$ bad som diffioulty thls spring with hls gorlel trawray loreaking but It 1a now repalrad and operating astialaotorily. At tas timo of a vialt, the proporty wo operating wth four or flve carp a day boing milled. Mr. Dawaon's v1fo, ma1l daughter, sloter, and joung nepbow were at the property. Mro. Dawbon and Mr. Dawton's slater took turng operating the mill wile Mr. Lawson worked the mine. Mr. Dawoon 
oxpocts to aill for apprordmately 100 shifts during 1948.

The ore structure at the Dawson mine is too plat dying for broken ore to flow freely in the stope. The poot will is amooth and unbroken but tho hanging wall is badly fractured. Kr. Dawson instats on openting too much ground in hils stopes without paoper

$\therefore$ aupport. He was advised againgt this but etill continues to mine in the same way. There is considereble danger that his hanging s. wall will atart to cave and that bis pregent atope bay be lost. i

l.1. Dawson reported extatence of two narrow $\left(4^{11}\right.$ to $\left.6^{A}\right)$ veing 4 on the sumult of the rountain on which he 1.3 located. He reports Leveral samples wore cut and went over one hundred dollars in gold a ton. The llountain was fopsed in and the aumit wa still coverod fith snow so no investigation was made. $\int$

June 30 - Dried out gear in $P_{*} A_{*} P_{*}$ cabin and over-hauled outbosrd rotor.

JuIy I - Yolis to Salt Chuck.

At the time of arrival, the proporty wa being shut down. Arthur Theis and his associates were forming tho Hontana Load and Zino Company with a view to toking over the major interest of the Kahoreg Mine on Coorge Inlet.

The epproximate 6,000 foot of raad from mine to mill was completed but nelther the atine or mill is in condition to operate. The writer was Informed that the reason for leaving was because of disagreament with

Stee and Guy Howara, onners of the property, and not beceuse of ay lack of orebody.

July 2 - Amired at Coel Bay. Happy Kontplenoure ohowed a mall Beam of Ilgntte exponed an the left benk of BIB Coal Bey atream and about $1 / 4$ mile from the beach. The seam aporages doout 10 inchos thick and dips about 12 degrees.to the north. It has an extremely bigh ash content. Spectmens of the coul refused to burn until thoroughly washod and dried. The soam wa underlain by slate. Above tho seam wag 6 to 8 feet of a poorly consolidated sandaton. There 1s from 5 to 50 leet of overburden above the sandstane. On exposure to the afr and drying, the sandistane wa noted to dialntegrato. Approximat oly one half milo to the osst, the slate and sandstane vere again exposed In a strom bed but no coel found in association with thom. The conl seam has no economic importance. The sandstane has no importanoe at present but may bave some local importance for linited uses in the futare. 
July 3 - To Kassan. Tolked with John Jufers regarding prospeots of Interaat. Buferg requested exanination of his "Copper Bing Prospect" at Procadero Ray. May oxamine later.

Rotumod to Kotohikan ria Frod hckay.

July 4- Roturned akiff to flarring Cove. Overtaulad outboard motar and returnod in ittitumooti.

Juzy 5-8 - At Ketshilkan.

July 9 - To Limo Point (Barite)

July 10 - Looked for reportad barite occurrence an ilve point.

Searohed point thoroughly but did not locate ony burite. In a draw

"on the oast ofle of the peningula and about 100 feet from the beach

an outcrop of guarts about 6 leet acrosa in the north-Bouth dimenaton, and 8 fert scross in the eastwost dirension is exposed. Ito dimenolons 2 re inaressing with depth. The guart\% is olean, conta ini no impurities and no minoralization.

July 11 - Lin Point to View Coos, Rall Island.

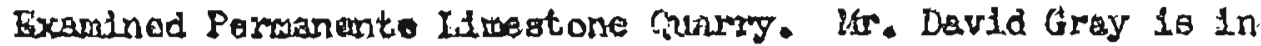
ohare of the oporation. An oraplayaent of 18 wero reportod at the property, broken down a follow:

1 Supertntandent - Daniel frisy

I Bookcteaper and wire - Mrs. Garretion

1 oook

2 mill

2 are train

2 churn d rilis

7. porer shotel

3 quarryr

2 powerhouse

2 blackanith ohop

Jormally, the operation of the property requires about 25 mon but 100 ware requifed for 1948 because of tho oxcollont eragmentation of a serpes of ahots in the fall of 1947. The property oporated for

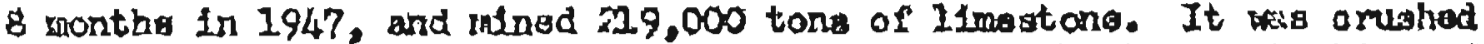

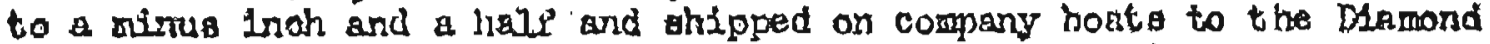
Divialon of Formonte Cawent Compeny in Yoatile. It is planned to operate unt11 the eirat of Decumber during 19148.

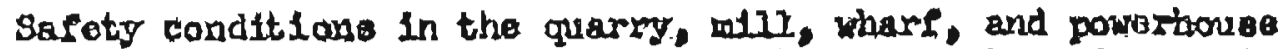
appeared to be good. A radlophore wa at the property and a trained muree was present at all times. 
VLew Cove to Ketohikan.

July $12-14$ - At Ketchitean.

! JuIy 15 - To Humpback Lako, Boos de Quadra, for Eugene Whacker Olajm oxamination. Mr. llacker bellever ha has locatod a body of carnot ite near Humpback labo. The trip was mede with Palmor stewart wio had previougly vigited the property with Mr. Hadrer.

July 16-18 - Prom Humpuack Lake to Wackor clalad and rotura.

The Hecker olatge are reachod by followng up a strear that

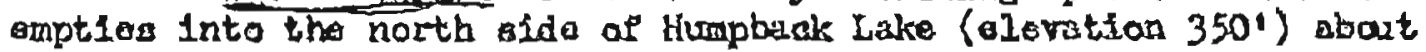
ano fourth mile from the upper ond. Tho atreas is followad about threo sourths of a mile to tho top of the rlage (elovation 2460\%). Tha supposed camotite outorops alsout three fourth of a mile to the north east and on tho north side of the ldgo top at an elevation of 2710 feet. The outarop is a bout half wry doin a several hundred foot shour alife face. Irary offort was mado to accure a samplo from tha outorop but it wa imposatbie. Therefora, the only samplos obtained were llat samplas eror tho draw below the outorop. These appoared to be Iinonite stains an diorite. However. sovoral piecen wore takon to the hetchlkan isay Offlce for touting. Hone, however, conthinod any radoative material.

Suly 1920. - Heathered in at Mumpback Lake. No plene.

July 21 - Roturn to Betohtkan.

July 22 - To silves Lake for gafety inspeotion of Ketchlicun liator Power Tunnel.

A contraot, asounting to $\$ 40,330.00$ wa given to An Erickson by the City of Katchitan for the purpose of completing the brazkthrough of the S1Iras Iave hungl into 811vas Lake. The cantract was ararded on Juno 17, 1948, and Kir. Eriolroon promised completion of tho tunnel by Ootober 15, 1948 .

At the tin of the Inspection, 34 . Erleks on was driving a 40-foot broak-through tuniel from 110,2 ralse in order to lower the lake about 15 feet. Plfteen feet of this tunnel was already complets. Two mare round of 6 foet oath and one lang roumd with 9 foot beak holes and 15

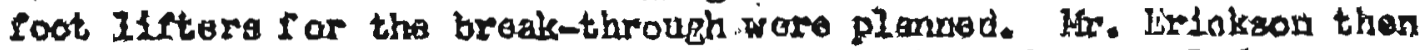
planned to drive a 42 foot $70^{\circ}$ miso fram the main tunnel for an additional breakmthrough there. In thia sanner, Mr. Brickan proposed to lowr the water in atages cut1l the lake la lowed to the deasred lovel. Th19 method calls for at least five soparate break-througho. 
Lir. Iricicson requested the aritarts opintan an the work prior to ble bld for the fob and prior to the relter'a Jolning the Doparto ment of kines. A methad was euggested and rojected bs lfr. ciriokson on the grounds that he was unfamilsor vith thet type of sork. At the tine of the inspotion, the witor's rethod was agaln suggegted and again rojectod. Since $\mathrm{Kr}$. Firickoon uns aprarontly conducting his wark in a sa meoner, no further counrent wag made.

Purladic inspection trips to this job were ragde.

It was reopmended to kír. Erlakaon that he place a guard rail around his surface exearation to eltritnate the hazard of a terloud 5all. Mr. Erickson assured the valter that it wald ba taken care af. In other reapucto, the job spfarently was baing conductod in a sare manaer.

The crow employed at the fob colselstod of five oinurg, one compressor zan, I cook and Arier Iriakson.

Poriodic ingpotion tripo to this job are roourmonded.

JuIy 23. - ileturn from Silvan Latio.

July $24-26$ - In Kotohikan.

July 27 - To Limo Point (Barite).

After obtalning further information on the loodtian of the

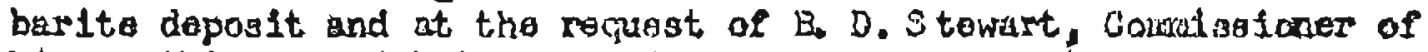
MInes, this second trip was de.

Th1o deposit, called the Burium Lado, wes part of the Gertrude

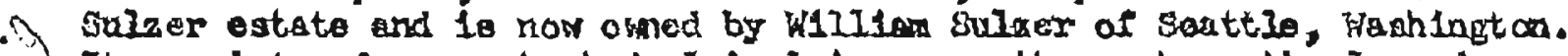

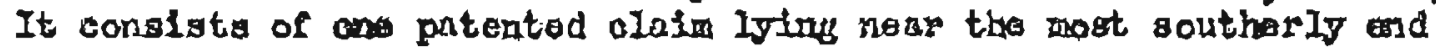
of the peningula betwoen Hetta and futlar Inlets, Prince of Heles Is Iand, Alastica.

Tho depostt is apparently a srall replacentent dopoalt of wite cryotaline barito with no violbio fmpuritieg lying in s sain aryetalina, blueweatherlig, white imotone. It apours to bo a nearly vertical tabular deposit with a generally northerly atrike. It oontaine an at ineted tonnage above low tide of a bout 4, 300 tong. It extends under the water on the south end. It depth has not bear. determined. There are about 35 leet of tunnel and 30 feot of opon cuts on the property. A whiteish appoaring roef eeveral hundred yarde to the southweet was investigated and found to be limeatcone. A report has been orrtitor and maps drawn on this property, and aro an 1130 In the Departmat of Hinea' 1103. 
July 28 - Like Point to Woonshine I aad Proparty.

A return was ade to this proporty bocanse the Sweotorrs' roported the phart and tunnel now opon.

July 29 - The tunnel at the Hoonghtne property is badly caved in In overal jiaces. It is not posasblo to reach the tunnel face but the Swetsers atute that it does not out the ore atruoture.

The Swertark did not lanve the shapt in oustable shape for anyone to rlsk going town whthout asglatanco rom a bova. However, it

$\therefore$ could bo seen thet the sweotsers had rewored some of the shaft logging in orcler to exanino exposed ore structures. Thio property 10 known to contaln some good ore. A aultable (f of the present condition of the workings. It is rocormended thite such a report be prepared, if positble, before tilla property becones complutely inaceseible.

July 30 - From Koonshine to Hiller (14trelal) Lake to looate a 2li-1nch veln of galena roported by pugene Waakor.

July 31 - Mr. Haolsex roported a 24-inch vein of galene on tho east alde of Dara lake and about one-fourth mile from the hesd. The in wo reported cut by a tunnal wbait one-fourth mile from the lake. Large plecen of galena Ilont were reported in tho atron bed below the turnel.

On Investigation, the tunnel was lookted. It had bean drivon for

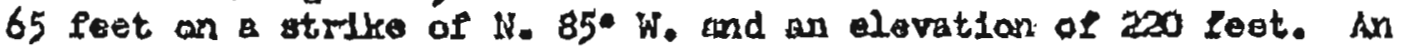

1. 9-foot orosemcut vas diriten to tho $r$ ight at 45 feet fraw the portal.

I. Ho ore was out at any place in the tunnel. No galons was found in tho. straam below. About 60 feot abova tho tunal en outoropowat 10 foet wdo war found that contas nod minute spook of galone and falf amounts (hof phalarite. Pyrite and ohalcomeste was also noted.

This outcrop is in 1 ine with and is probalily a continustion of the Iracy of the Lake veln. Two samplos were cut.

\begin{tabular}{|c|c|c|c|c|c|}
\hline $\begin{array}{l}\text { Samplo No. } \\
\text { MMP-27? } \\
\text { MAT-28 }\end{array}$ & $\frac{\text { Hidth }}{\text { Io }}$ & 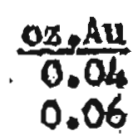 & 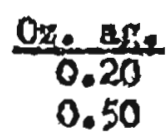 & $\frac{\& \mathrm{~Pb}}{1.80}$ & $\frac{\frac{87 n}{7.7}}{17.45}$ \\
\hline
\end{tabular}

August 1 - HIlex Lake to Ketchtkan. 